\title{
Legal Implication of Quran Chapter 4 Verse 3 on Muslims' Marital Affairs
}

\author{
Ahmed Abiodun Muhammed-Mikaaeel ${ }^{1}$ \\ ${ }^{1}$ Faculty of Law, Kwara State University, Nigeria \\ ahmed.muhammed-mikaaeel@kwasu.edu.ng
}

\begin{abstract}
Introduction to The Problem: Bad practice of polygyny among certain members of Muslim Ummah is nothing to write home about. The practice does not conform to Islamic teachings as contained in the unambiguous provision of the ordinance in Quran Chapter 4 verse 3 . The very essence of Islamic polygyny, which is geared towards protecting the interest of widows and orphan girls, is defeated among the bad practitioners of polygyny. This has resulted in ardent opposition to the practice of Islamic polygyny. The foregoing informs the reason this paper examines the legal implication of Chapter 4 verse 3 on Muslims' marital affairs.
\end{abstract}

Purpose/Objective Study: The objective of this paper is to examine the genesis and subject matter of Chapter 4 verse 3 , the legal implication of Chapter 4 verse 3 , and the juristic opinion on Islamic polygyny, the Muslims bad practice vis-à-vis the reality on Islamic polygyny.

Design/Methodology/Approach: The methodology employed in this paper is simply the doctrinal method of legal research. To the end, the paper relies the provisions of the Quran, Hadith, Juristic Views, and scholarly articles written on the subject matter of this paper.

Findings: The paper reveals that the primary objectives of the legal implication of Chapter 4 verse 3 include the protection of widows, orphan girls and divorcees; abolition of unjust/bad practices in marital affairs; payment of adequate dowry to women in the event of marriage irrespective of whose ox is gored; and satisfaction of man's desire for women and outright abolition of Zina. The paper discovers that the practice of polygyny has continued to be relevant in view of the incessant pressing needs for it. The paper also finds that the greatest challenges to Islamic polygyny are inherent in the Muslim Ummah, both on the parts of men and women. The paper recommends character adjustment for both sexes to pave the way for the true practice of Islamic polygyny.

Paper Type: Research Article

Keywords: Legal Implication; Quran; Ayāt Aḥkām; Marital Life; Islamic Polygyny

\section{Introduction}

The polygamous system of marriage has permeated every corner of the universe though practiced in a secret manner in a certain region. It is one of the oldest traditions on earth (Mwambene, 2017). Polygamy as a system of marriage connotes the marriage of a man to more than one wife at the same time (Lawson \& Gibson, 
2018). Allah SWT, in the sphere of marital affairs, does not leave Muslims to do what they like. Through adequate legislation in the Holy Quran, the Law Giver regulates the polygamous system of marriage under Sharia (Quran Chapter 4 verse 3). This is, therefore, the fulcrum of Chapter 4 verse 3, which makes provision for restricted polygyny with due observance of justice towards wives. This means that the maximum number of wives a man can marry at the same time is four.

Despite the clear legislation in the verse under reference with respect to the objective of the Law Giver and rationale behind the revelation of the verse, there were reports from different quarters that the practices/attitudes of Muslims (men and women) towards Islamic polygyny were in the negative (Mwambene, 2017). The rationale and objectives towards the revelation of the Quran Chapter 4 verse 3 are to ensure fair treatment of wives in marital relationships. This sphere of fair and equitable treatment covers from the inception of the marriage contract throughout the duration of the marriage. That is why Allah places emphasis payment of adequate $M a h r$ (Dowry) notwithstanding her status be it divorcee, widow, orphan girl, etc. It is observed in Malaysia, for instance, that women are facing certain obstacles day-inday-out. One of the obstacles said to have been faced by these women was born out of bad polygyny practice, thereby creating the bad perception of polygyny practice amongst women folk (Shih et al., 2017).

From international human rights perspective, the bad practice of polygyny has been tagged as one of the challenges to exercise women's guaranteed rights. This has made some countries consider banning polygyny practice with a view to allowing women freedom to exercise their universally recognized rights (Albader, 2019). In the same token, the bad practice of polygyny has been identified as one of the reasons that have caused the criticism against polygyny as being an illegitimate practice. The bad practice is associated with denial of women's rights and girl-child in the matrimonial environment, which has attracted the attention of international human rights activists and worldwide criticism (Mwambene, 2017).

Apart from the negative impact of bad polygyny practice on the woman folk, children are not left behind. A study has revealed the negative effect of bad polygyny practice on children's behavioral, emotional and academic dispositions. To this end, bad polygyny practice has a resultant harmful effect on children's overall growth processes and what they stand to become in the future. It has been argued in a certain quarter that bad polygyny practice since the early twentieth century had occasioned social problems as a result of neglect of wives and children such that. In Indonesia, polygamous marriages are negatively perceived, especially by the first wives and their relatives (Behaghel \& Lambert, 2017). Therefore, the bad polygyny practice has a long-term negative effect on the spouses and their immediate families (Rogozen, 2017). From the principle of equality and inequality, bad polygyny practice has been perceived as an unwarranted practice that greatly breeds inequality among spouses, especially when the husband becomes unjust to the co-wives (Krieger \& Renner, 
2018). More so, the inequality occasioned through the bad polygyny practice has the effect of resulting in social and civil unrest as well as political stability within a particular nation (Krieger \& Renner, 2020).

The bad practice of polygyny often time came to the fore through insignificant reasons. Some husbands, who practice polygyny, have parochial reasons spurring them into polygyny practice without adequate preparation (Ross et al., 2018). The unnecessary desire for the male child where the existing wife or wives is or are producing female child has been one of the insignificant reasons such that the wives are not accorded deserved treatment as long as they continue to give birth to the female child (Ross et al., 2018). To this end, the bad practice inherent in the polygyny practice has made a certain group of women advocate stringent condition(s) for Muslims' polygyny practice as a form of measure to prevent abuse (Fowzul \& Haneef, 2020).

In view of the foregoing, this paper seeks to examine the provision of Chapter 4 verse 3, being one of the Āyāt Ahkām in the Holy Quran, vis-à-vis its legal implication on the Muslims' marital affairs with a view to proffering necessary recommendation. Therefore, this paper intends to make a meaningful contribution to knowledge, especially by clarifying the various controversies surrounding the trite application of Quran Chapter 4 verse 3 thereby serving as reference paper to the Muslims' polygyny practitioners and the intending polygyny practitioners, policymakers, and Muslims all over the world.

\section{Methodology}

The methodology employed in this paper is a doctrinal method of legal research. To the end, the paper relies on the various relevant provisions of the Quran to draw several implications for the main provision in focus (i.e., Quran Chapter 4 verse 3). Thus, other verses of the Holy Quran were relied on to explain Quran Chapter 4 verse 3. Apart from the foregoing, the paper also relies on Hadith and Juristic views vis-àvis the interpretation of Quran Chapter 4 verse 3 with a view to drawing a clear understanding of the implication of the verse. In the same token, the paper also makes use of textbook(s), articles in journals, and other relevant internet material with a view to achieving the objective set for the study.

\section{Results and Discussion}

\section{Conceptual Analysis}

The verses of the Holy Quran are typically referred to as Ayāt in Arabic connotation. (Salman, 2019). Generally, all the verses of the chapters of the Holy Quran are important in that they serve one propose or the other. Allah SWT has enjoined the believers, in a number of the verses of the Holy Quran, to ruminate over those verses (Quran Chapter 59 verse 2). This shows the importance of each of the verses of the Holy Quran. However, within the context of this paper, credence is given to some verses that are legal injunctions of the Law Giver, which are meant to be followed to 
the latter disobedience of which attracts punishment. The verses within this context are technically referred to as Āyāt Ahkām, i.e., verse of legal injunctions from the Holy Quran (Quran Chapter 3 verse 7). To this end, Āyāt Ahkām are numerous in the Holy Quran, but the focus of this paper is the provisions of Quran Chapter 4 verse 3.

This verse, is no doubt, one of the Ayyatt Ahkām in the Holy Quran because it contains certain legal injunctions that are to be carried out by the person(s) to whom the injunction is mandatory upon, i.e., Mukallaf (Ismail, 2020). Quran Chapter 4 verse 3 depicts marriage as an important institution under Sharia, the purpose of which is to promote love among the couples and not otherwise; to enhance procreation which in turn increases the numbers of worshippers on earth; and to block any way that may tempt mankind to engage in the odious and atrocious act of Zinā (Ozyigit, 2017).

Allah's knowledge and wisdom over all His creations are unquantifiable (Quran Chapter 2 verse 32). The wisdom behind the legislation in Quran Chapter 4 verse 3 is to regulate and satisfy the usual desires of men towards the opposite sex. The Law Giver does not deny them to marry more than one wife but only gives the maximum number of wives they can marry at a time. Invariably, the provisions of Quran Chapter 4 verse 3 legislates restricted polygamy for Islamic marital practices (Lawson \& Gibson, 2018). Apart from the satisfaction of man's desires for women, the verse also strikes a balance regarding the geometric population of women to men in which many women are without husbands. Worse still is the increase in the incidence of divorces and deaths of husbands, thereby exposing the divorcees and the widows to the societal temptation of Zina (Rahman et al., 2018). The practices at the time of Prophet Muhammad (SAW) were to use the institution of restricted polygamy to the benefit of the divorcees and widows as a form of Jihād (Mwambene, 2017). Like many verses of the Holy Quran, especially the Āyāt Ahkām, the provision of Quran Chapter 4 verse 3 enjoys certain rationale behind its revelation as shall be discussed in the section below.

\section{The Genesis of Quran Chapter 4 Verse 3}

By the genesis of Quran Chapter 4 verse 3, what is intended is the rationale behind the revelation of Quran Chapter 4 verse 3. Before delving into the rationale behind the revelation of Quran Chapter 4 verse 3, it is imperative to reproduce the meaning of the verse thus:

"And if you fear that you will not deal justly with the orphan girls, then marry those that please you of (others) women, two or three or four. But if you fear that you will not be just, them (marry only) one or those your right hand possesses. That is more suitable that you may not incline to (injustice)."

According to As-Sa'di, in his Tafsir of Quran Chapter 4 verse 3, contends that if a man feels he will not be just and fair to the orphan girl under his guardianship and that he is not likely to fulfill their rights because she is not attracted to him, the Law Giver has given him permission to marry other women rather than marrying her with pity. Because doing so will affect his obligation to do justice in the course of the marriage. 
(As-Sa'di, 2018). Marrying other women who seem good to you in verse indicates that Muslim men are not permitted to marry bad women such as immoral women and polytheist women.

The considerations for marrying women under Sharia signify that a man must do a thorough finding of the woman he wants to marry, in which case, the law permits him to look at her face to ensure that he has adequate affection for her. This is geared towards ensuring love and cares that later transforms into great zeal on the part of the husband to treat the wife fairly and justly as stipulated by Sharia. Thus, the verse gives men latitude to marry two, three, or four wives so as to satisfy the desires of men for more than one wife but on no circumstance should a man marry more than four wives at a time (As-Sa'di, 2018).

It must be noted that the latitude to therefore marry more than one wife is not absolute in that a condition just dealing among the wives is attached. If a man is not sure of dealing justly with the wives, then it is better for him to abstain from polygyny than to put himself in a situation that will jeopardize his religion in the hereafter. This is because marriage is not an end itself, but a means to an end in the sense that other obligations placed on the husband such as to paying commensurate dowry to orphan girls taken in marriage or other women, dealing with wives justly, providing for them fairly and equitably amongst other duties within the capacity of the husband must be fulfilled (As-Sa'di, 2018). Therefore, the operative part of Quran Chapter 4 verse 3, which indicates the rationale behind its revelation, is: "And if you fear that you will not deal justly with the orphan girls ....."

The crude meaning of this verse is that the Law Giver gave a command that if one happens to be the caretaker of a female orphan, and he fears that he may not give her Mahr (dowry) that is suitable for women of her status, then, he should marry other women as the Law-Giver has not restricted him to marry the orphan in the circumstance. The rationale behind the revelation of the verse is contained in the statements of Aishah bint Abu Bakr, the wife of the Messenger of Allah, Prophet Muhammad (PBUH). To this end, Aishah (R.A) was reported to have said:

"A man was taking care of a female orphan and he married her, although he did not desire to marry her. That girl's money was mixed with his, and he was keeping her portion from her. Afterwards, this Ayat was revealed about his case: If you fear that you shall not be able to deal justly with the orphan girls, then marry those that please you of (other) women, two, three or four ...." (Ibn Kathir, 2021).

Also, in another narration, Urwah bin Az-Zubayr was reported to have asked Aishah (R.A) about the meaning of the statement contained in the introductory part of the verse (i.e., Quran Chapter 4 verse 3), and Aishah (R.A) responded thus:

"O my nephew! This is about the orphan girl who lives with her guardian and shares his property. Her wealth and beauty may tempt him to marry her without giving her an adequate dowry which might have been given by 
another suitor. So, such guardians were forbidden to marry such orphan girls unless they treated them justly and gave them the most suitable dowry; otherwise, they were ordered to marry woman besides them" (Ibn Kathir, 2021).

Aishah (R.A.) stated further as follows:

"After that verse, the people again asked the Messenger of Allah (about marriage with orphan girls), so Allah revealed the Ayat, (they ask your instruction concerning the women ....) and Allah's statement in this Ayat, (yet whom you desire to marry) refers to the guardian who does not desire to marry an orphan girl under his supervision because she is neither wealthy nor beautiful. The guardians were forbidden to marry their orphan girls possessing property and beauty without being just to them, as they generally refrain from marrying them (when they were neither beautiful nor wealthy)" (Ibn Kathir, 2021).

It could be inferred from the above that the rationale behind the revelation of the Quran Chapter 4 verse 3 was deeply rooted in the unjust dealing with orphan girls by their guardians who married them. Allah SWT revealed this verse to put an end to the unjust practices as a form of protection for the orphan girls. The verse, therefore, laid down the importance of the right of women in marriage to an adequate amount of Mahr (dowry) satisfactory to them without any element of coercion, inducement, or misrepresentation (Ferdousi, 2019). Thus, the subject matter of the verse is nothing but the concept of marriage under Sharia.

\section{Subject Matter of Quran Chapter 4 Verse 3}

The revelation of the Quran Chapter 4 verse 3 principally addresses the concept of marriage under Sharia. Under the Sharia legal system, marriage technically connotes the union of a man and woman as husband and wife with the satisfaction of the religious rites attached to it in the form of condition precedent (Sharmin \& Azad, 2018). The Law Giver forbids Zina (Quran Chapter 24 verse 2) but permits marriage with the fulfillment of condition precedents such as offer, acceptance, consent of the Wāli (guardian), payment of Mahr (dowry), and availability of witnesses (Quran Chapter 4 verse 3 ). The concept of forced or forcible or involuntary marriage has no place under Sharia. This is because both the husband and wife have certain rights and obligations. Marriage does not change the wife into a slave but a marital partner to her husband (Sharmin \& Azad, 2018).

Thus, the Law Giver in the Quran Chapter 4 verse 3 under reference permits a Muslim man to marry up to four with the condition that he must be capable to do so and he is able to keep them in accordance with Sharia (Nuhu, 2018). Thus, limited polygyny is sanctioned in verse. It is worthy of note that the interpretation of the verse has been subjected to unscrupulous interpretation by the Zahirites who contended that the word maśna in verse signifies, 'two, two'; sulasia signifies 'three, three'; rubä'a signifies 'four, four' and by implication places the number of wives permitted to marry under Sharia to be eighteen. However, Muslims must disregard this kind of interpretation. 
The reason being that the trite position remains that the verse only permitted restricted polygyny of not more than four wives at a time. This informs the reason Imam Shafi'i posited that it is not lawful for any Muslim other than the Prophet (PBUH) to marry more than four wives at a given time. In the same vein, the Prophet (PBUH) was reported to have said: "The Prophet said to Ghilan bin Umayah al-Thaqafi who had just accepted Islam and had ten wives: "choose four out of them and give up all other" (Bidin et al., 2017).

Under some legal systems, the concept of marriage is viewed as the union between a man and a woman to the exclusion of others (Grossbard \& Vernon, 2014). This view cannot stand under Sharia. The reason being that every marriage contracted in accordance with Islamic rites is potentially polygamous in nature. Thus, by virtue of the Quran Chapter 4 verse 3, Allah (SWT) has made lawful for believing Muslim men the right to practice restricted polygamy. It is therefore unlawful for a Muslim to make unlawful for himself what the Law Giver had made lawful for him (Quran Chapter 66 verse 1). This is because the so-called western civilization has affected a number of Muslims in the recent time by abhorring the Islamically regulated polygamous marriage and stick to the practice of monogamous even in the circumstances when it becomes obligatory for them to marry more than one wife while they engaged in Zin $\bar{a}$ (Ozyigit, 2017). This is borne out of the misinterpretation of Chapter 4 verse 3 of the Holy Quran. The foregoing serves as a background to the examination of the legal implication of the injunction contained in Quran Chapter 4 verses 3.

\section{Legal Implication of Quran Chapter 4 Verse 3}

The legal implication here connotes deductible rules from the content of the verse under reference. This is one of the features (Ahmad et al., 2018) that qualify the verse as one of Ayāt Ahkām in the Holy Quran. The notion of marriage under Sharia is that contract existing between man and the woman after fulfillment of the condition precedent (Ishola and Abdulrahman, 2018). This notion of marriage had been so since the inception of creation and nothing shall change it. Thus, the idea of marriage is that which is restricted to a union between two opposite sexes, i.e., a man and a woman.

The concept of marriage as a necessary implication from the verse is that Islamic marriage is polygamous in nature (Quran Chapter 4 verse 3 ). However, it is not openended polygamy because Allah SWT has given the maximum number of wives a man can marry at a time which must not exceed four (Bidin et al., 2017). Some cultural practices do not regulate or give restrictions to the number of wives a man can marry at a time (Olasore, 2016). Such cultural practices cannot be imported into Muslim practice in order to avoid the wrath of the Law Giver. The reason is that Muslim men are not allowed to marry beyond four wives at a time because marrying more than four, no doubt is an invitation to tormenting punishment of the Law Giver as it amounts to transgressing the limit set by Him. A Muslim man who marries beyond the maximum of four wives at a time will be deemed to have been committing Zinā with other wives i.e., from the $5^{\text {th }}$ and above (Muhammed-Mikaaeel, 2020a). 
The Muslim jurists opined that the original case with respect to sexual intercourse is that it is generally forbidden except with one's legal spouses. The juristic opinion is derived from the provision of Quran Chapter 23 verses 5-7. Thus, it is a valid marriage that licenses or legalizes a sexual relationship between a man and a woman. Sharia does not only prohibit premarital sexual intercourse but also provides a serious sanction in the form of punishment under the Islamic law of crimes (MuhammedMikaaeel, 2020a). The reason being that it is unlawful for a man to donate his semen to a woman whom he has no right over (Quran Chapter 24 verse 2). This, therefore, depicts the great importance attached to the payment of Mahr (Dowry) as one of the condition precedents to the validity of the marriage under Sharia (Ferdousi, 2019). This is one of the central points of Quran Chapter 4 verse 3 under reference to the extent that the Law Giver forbids guardians who had been taking care of orphan girls under them from marrying them without a dowry. The Law Giver frowned at the practice and tagged it as an inclination to injustice (Ibn Kathir, 2021).

It is legally implied from Quran Chapter 4 verse 3 that the existence of marriage places enormous obligations on the husband to deal justly with his wives (Arabian, 2016). Among the duties of the husband is a payment of Mahr (dowry), the bearing of wives' living expenses, avoidance of cruelty to the wives, avoidance of any form of injury and oppression to the wives, and dealing with them equally and justly (Arabian, 2016). The aspect of dealing equally and justly thus becomes technical in the sense that it is stated in the Holy Quran that: "You will never be able to do perfect justice between your wives even if it is your ardent desire" (Quran Chapter 4 verse 129).

The above statement does not mean that restricted polygyny is by necessary implication abrogated. What the statement portends is that it is difficult to perfectly do justice between wives. Perfection indeed belongs to the Law Giver. That is why Ibn Kathir, while explaining the verse, opined that it is not obligatory to treat them equally but rather, it is recommended act such that if one does it, it is good for him; and if he is unable to do that, there is no harm on him. Sheikh Muhammad bin Sirin contends further, in the same vein, that the inability referred to in verse bothers on love and sexual intercourse (Sharmin \& Azad, 2018). On the issue of loving wives equally, Sheikh Abubakr bin al-Arabi posited that no one could control one's heart in this respect because it is entirely in the hands of Allah (SWT) (Sharmin \& Azad, 2018). This does not, however, give license to men to perpetuate injustice towards their wives as the Prophet (PBUH) warns that any man who marries more than one wife and deals unjustly with them will be resurrected on the Day of Qiyāmah with half of his faculties paralyzed (Bidin et al., 2017).

Thus, as a matter of fact, wives come from different backgrounds and are accustomed to different tastes. This fact assists man to deal with the wives in accordance to their respective tastes not necessarily equally. According to the Messenger of Allah (PBUH), he is of the view that when it comes to the matter of love among the wives, no one can guaranty perfection or justice (Husain, 2019). Nevertheless, it is not a bar to marrying 


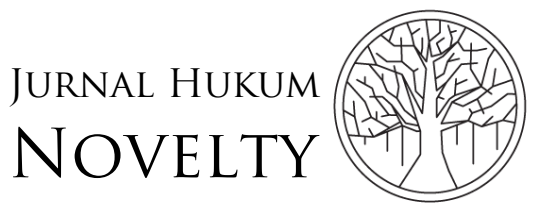

Volume 12, Issue 02, 2021, pp. 204-224

P-ISSN: 1412-6834

E-ISSN: 2550-0090

more than one wife, but one must do what is humanly possible within his capacity to avoid perpetuating injustices among his wives (Husain, 2019).

The usual misinterpretation of Quran Chapter 4 verse 3 on the basis of Quran Chapter 4 verse 129 is further clarified by another verse of the Holy (Quran Chapter 4 verse 4), which meaning reads thus "And they seek of thee the decision of the law concerning marriage with more than one. Say Allah gives you His decision concerning them. And that which is recited to you elsewhere in the Book." Therefore, the foregoing leads credence to the conclusion that polygamous marriage in restricted form is unequivocally permitted by the Law Giver. With respect to dealing with wives equally, it is stated that: "We confine the imposition of the duty of equality to sharing the time only. That indicates that it does not apply to other matters like maintenance, love and cohabitation (Ambali, 2014)". Thus, by implication, the ultimate objectives of marriage in Islamic jurisprudence, among others, include (Ambali, 2014):

1. Protection against moral and spiritual maladies and abuse of womanhood;

2. Protection of orphans;

3. Provisions of husbands for widows who have not passed the age of marriage;

4. Provision of another chance for the women whose earlier marriages have collapsed and are willing to have another trial.

The principal implication of the foregoing is that Zinā (unlawful sexual intercourse) in whatever guise is forbidden (Quran Chapter 24 verse 2). Apart from the fact that Zinā is forbidden under Sharia, it also opens doors to other unimaginable evils (Quran Chapter 17 verse 32). It is a serious threat to the objective of Sharia which seeks to protect family lineage among others (Quran Chapter 17 verse 32). Through Zinā, social miscreants are a breed that later constitutes a great threat to society at large, as it is being witnessed in recent times (Gusau, 2021).

Marriage, especially restricted polygyny, is, therefore, an act of ' $I b \bar{a} d a h$ which must be practiced in the best form pleasing to Law Giver. The Prophet Muhammad (PBUH) was reported to have said: "If a man marries, he had fulfilled half of his religion. Let him fear Allah regarding the remaining half" (Naseem, 2019). It is, however, important to note that within the purview of Quran Chapter 4 verse 3, Muslim scholars seemed to have preferred Islamic monogamy for fear of perpetuation of injustice amongst their wives.

\section{Juristic Opinion towards Islamic Polygyny}

The Imams of the four Mażhabs have not put forward a clear-cut position on Islamic polygyny practice, unlike their positions put forward in the event of first marriage (Bidin et al., 2017). They were inclined to polygyny practice as beautifully practiced during the time of Prophet Muhammad (PBUH) (Husain et al., 2019). This is because the practice during the time of the Prophet (PBUH) was devoid of abuse and injustice as inherently evident in recent times. Little wonder the four Mażhabs seemed to support polygyny practice without outright prohibition (Husain et al., 2019). Thus, 
the issue of polygyny as contained in Quran Chapter 4 verse 3 is devoid of juristic arguments amongst the Mażhabs with respect to the permission and restriction in deserving cases. This is in view of the fact the provisions of the Quran and Hadith remain unambiguous to the polygyny practice save for application in recent time.

Ash-Shirbeeni of Imam Shafi'i Mażhab posits that: "It is a Sunnah not to marry more than one wife if there is no apparent need" (Davary, 2016). In the same vein, AlMawardi of Mażhab Imam Shafi'i asserts that: "Allah has permitted a man to marry up to four wives, saying: (... two or three or four....), but Allah advised that it is desirable for man to marry only one wife saying, "but if you fear that you will not be just, then marry only one" (Davary, 2016). A scholar from Imam Hambali Mażhab, Ibn Qudamah, opines that "It is more appropriate to marry only one wife". The contribution of Imam Ahmad Ibn Naqib al-Masri of Imam Shafi'i Mażhab is on all fours with the foregoing when he says: "It is fitter to confine oneself to just one" (Davary, 2016). Another scholar from Mażhab Imam Shaffi'i, Imam Ghazali states that: "It does not call for two wives (since) plurality may render life miserable and disrupt the affairs of the home" (Ahmed, 2021). It must be noted that notwithstanding the individual juristic opinions above, the ruling in Islamic jurisprudence is that it is not permissible for a husband to go into polygyny if he is unable to deal justly with his wives. It is outrightly harām (forbidden) for an unjust husband to dabble into polygyny in view of the negative consequence in form of wrath of Creator in the Day of Qiyāmah (As-Sa'di, 2018).

Sharia Courts, in countries like Malaysia and Indonesia, frown against polygyny practice that seems to be harmful to the existing wife or wives. That is why the Court had, in a number of cases, refused to grant permission to the husband to marry additional wife, especially where the conditions stipulated by the law were not met and where the wife too declined consent to the second marriage (Abdullah \& Khairuddin, 2009). Thus, the attitude of the Sharia Court, in the climes like Malaysia and Indonesia, to granting permission to practice polygyny is that of rarity. Notwithstanding the foregoing, the importance of the restricted polygyny permitted by the Law Giver cannot be over-emphasized. This is because there are circumstances that may make it to be indispensable save for the nature of man who are prone to injustices, especially in the circumstance of marrying more than one wife.

\section{Bad Practice among Muslims}

There cannot be an appropriate circumstance to draw a demarcating line between Muslim practice and Islamic teachings than the event of Islamic polygamous practice by Muslims (Albaghli \& Carlucci, 2020). Before going into the details, it is imperative to first and foremost state that the attitudes of Muslims nowadays to marriage generally are nothing to write home about. Most of the practices exhibited by Muslims are anathema to the dictates and teachings of Sharia (Albaghli \& Carlucci, 2020). It is not uncommon to witness Muslims living as couples in contravention of the provision of Quran Chapter 4 verse 3. That is, cohabiting and copulating without contracting 
valid Nikāh known to Islamic law. Most first-born children these days have fallen victim of being product of Zina (Aminu, 2015). Worse still is the disposition of some parents to confirmed pregnancy before Nikāh. Some parents would tell their proposed Son-in-law that it is after he is able to impregnate their daughter before they can consent to a contract of the proposed marriage between them, thereby encouraging them to engage in several acts of Zina before they finally tie the knot (Annie, 2016). Some Muslim men went into polygamy without fulfilling the condition precedent (Batagarawa \& Yahaya, 2018). For instance, some men have not been able to take care of their wives or even abandoned their obligation towards them but still went for the second wife. They just practice polygamy without fulfilling its conditions, such as the provision of food and shelter for the wives (Batagarawa \& Yahaya, 2018).

The bad practice inherent among these weak Muslims has made some Muslim women absolutely abhor Islamic polygyny to the extent that some are ready to divorce their husbands should they take up the second wife. Some who are hard-hearted are prepared to go to any length to frustrate the polygamous dream of their husbands. Some Muslim men also abused the permission granted them in Quran Chapter 4 verse 3 by marrying more than the legal maximum. They, at times, rely on the obnoxious interpretation of the Holy Quran to satisfy their ego-centric interest by employing alien terminology such as the retirement of the earlier wives while still keeping them under their roofs against the sound interpretation by the Muslim scholars (Hashemian, 2020).

Most second marriages were done secretly and kept the wives and her relatives from being aware of the second marriage, which is unlawful under Sharia (As-Sa'di, 2018). Immediately the first wife is aware of the unlawful marriage that is the beginning of domestic violence (Arthi \& Fenske, 2018). Little wonder most bad polygyny practices breed domestic violence. Although it is a criminal offense, most affected wives rather sought divorce to get rid of the domestic violence as against prosecuting their husbands (Arthi \& Fenske, 2018).

With the enactment of Islamic Family Law in Malaysia, Sharia Courts have been faced with a number of cases in which they had to decide one way or the other with a view to ensuring that polygyny practice is not bastardized. The case of Aisha Abdul Raof vs. Wan Yusuf7 JH 152 (1990) is notable. In this case, Yusuf, a financially stable engineer, applied for permission at Sharia Court to marry a second wife. Apart from his financial capability to support his wives, one of his reasons before the Court was the apprehension of committing Zinā with the proposed second wife if the request was turned down. Based on the request by the husband, the Sharia Court was satisfied and granted permission to marry the second wife. The first wife, being dissatisfied, appealed to the Court of Appeal as a result of which the Court of Appeal set aside the permission and allowed the appeal on the ground that the Lower Sharia Court only considered the aspect of financial capability without considering other conditions which are of equally important. The Court of Appeal thus held that guarantee to 
support the wives and family members is insufficient to grant permission, having failed to establish that the second marriage is necessary as a result of the wife's incapability to discharge conjugal duties amongst others (Abdullah \& Khairuddin, 2009).

In another case with similar facts, the Sharia High Court situated at Shah Alam Selangor overruled the decision for refusal to grant permission by the lower Court in a confusing manner. The Lower Sharia Court had earlier refused to grant permission to marry a second wife on the grant that financial capability is insufficient since the wife was still mentally, physically, and sexually fit. On appeal by the husband, the overruled earlier decision and held otherwise that financial capability of the husband to support his wives and dependents is sufficient to fulfill the conditions stipulated in section 23(5)(b) of Islamic Family Law (Abdullah \& Khairuddin, 2009).

The way and manner Muslims practice Islamic polygyny nowadays calls for serious concern by Sharia Court exercising caution when it comes to the consideration of applications for permission for polygyny practice (Abdullah \& Khairuddin, 2009). However, the fact still remains that the Islamic world cannot do without the polygyny permitted under Sharia to salvage marital dreams of the influx of husbandless women and to discourage illicit sexual relationships.

\section{The reality of Polygyny in the Recent Time}

It is not grain said that the number of the population of women to men is of unimaginable margin. The population of women continues to increase geometrically day-in-day-out. Apart from this, the death of husbands is on the increase while the population of the widows continues to increase (Ross et al., 2018). More so, the population of divorced women does not cease to increase. The foregoing points irresistibly to the fact that the only available option to be evenly engaged in marriage is through the sound practice of Islamic polygyny (Husain, 2019).

The provision of Quran Chapter 4 verse 3 was revealed after the Battle of Uhud, which witnessed the death of many male Muslims thereby leaving widows and orphan girls to the care of the limited surviving male Muslims (Ferdousi, 2019). The aftermath of the Battle led to an increase in the number of widows and orphan girls. Such a situation has continued to repeat itself in a recurrent manner till the recent time. Thus, polygyny will continue to be relevant which means, Muslim men must buckle up their belt to practice it as laid down by the law. It must be noted that the requirement of justice in Quran Chapter 4 verse 3 automatically rules out the notion of "Secondary Wife" because all wives have exactly the same status because they are entitled to their husband in the equal right (Quran Chapter 4 verse 3). As rewarding as the practice of polygyny is, it is equally instructive to note that any Muslim man who practices polygyny by unjustly inclining one of the wives to the detriment of the others is promised a bad consequence of the act in the Hereafter (Husain, 2019). It must equally be noted that it is unjust on the part of any Muslim woman to insist that 


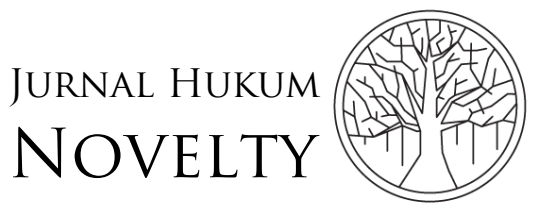

Volume 12, Issue 02, 2021, pp. 204-224

P-ISSN: 1412-6834

E-ISSN: 2550-0090

she is not ready to share her husband with a fellow Muslim woman. This insistence shows a lack or weak faith on the part of Muslim women (Quran Chapter 33 verse 36).

The Prophet Muhammad (SAW) was reported to have said: "You will never be able to attain righteousness until you desire for your brother (or sister) what you desire for yourself" (Ash-Shaqawy, 2021). To showcase the continued relevance of polygyny, Jamal Badawi hypothetically orchestrated thus:

"A man who discovers that his wife is barren, and who at the same time instinctively aspires to have children and heir. In a situation as this, then man would either have to: a) Suffer deprivation of fatherhood for life; b) Divorce his barren wife and get married to another woman who is not barren" (Badawi, 2021).

Badawi, while resolving the hypothetical problem, asserts that neither of the alternatives above could best solve the situation than polygyny which would have the advantage of preserving the marital relationship without depriving the man of fathering children of his own (Badawi, 2021). In another hypothetical problem given by Badawi, he stated that:

"A man whose wife becomes chronically ill would have one of possible alternatives: a) He may suppress his instinctive sexual needs for the rest of his life; b) He may divorce his sick wife at a time when she needs his compassion most, and get married to another woman, thus legally satisfying his instinctive needs; c) Or he could compromise by keeping his sick wife, and secretly take for himself one or more illicit sex partners" (Badawi, 2021).

In Nigerian clime, the issue of Islamic polygyny does not enjoy a separate legal framework, unlike the conventional marriage system (see Matrimonial Causes Act, Cap. 220, Laws of the Federation of Nigeria, 2004). The raw application of the primary sources of Sharia is usually applied in the law court if need be. This is despite the fact that Islamic law is one of the legal systems recognized in the Constitution of the Federal Republic of Nigeria, 1999, as amended (Hassan-Bello, 2019). Thus, unlike in certain jurisdictions, there is no separate legal framework regulating polygyny practice in Nigeria. More so, the issue of polygyny practice is not usually litigated in Sharia Courts. The bulk of Shariah Courts' cases bother on inheritance, maintenance, paternity, and other aspects of Islamic personal matters. There is virtually no reported case bothering on the issue of polygyny. However, the Nigerian case of Falmata v. Awana Zarami is worthy of mention (Case No. 27/94, Kuje Area Court 2). In Falmata's case, the Court made the pronouncement on the Islamic principle of equal treatment of wives in Islamic polygyny practice by holding that all the wives married to a particular husband in the spirit of the Quran Chapter 4 verse 3 are entitled to fair and equal treatment. It must therefore be noted that court permission is not a prerequisite to practicing polygyny in Nigeria.

In view of the intricacies involved in polygyny practice, certain countries have stepped forward to regulate the practice in their Laws. Examples of those Laws are the Islamic Family Law of Malaysia and the Indonesian Marriage Law of 1974 (Nisa, 
2016). Placing emphasis on the Indonesian Marriage Law of 1974, the law has been laudable since it encapsulates the erstwhile colonial Civil Code, Ordinance for Indonesian Christians and Adat/Islamic Law. The hallmark of the law is the prevention of bad polygyny practices and violence against women in their respective matrimonial homes (Nisa, 2016).

Thus, the Marriage law does not only regulates polygyny practice but also makes it difficult to practice legally with a view to preventing associated abuses such as domestic violence and consequent divorce. This is because every Indonesian marriage is, in principle, monogamous in nature (Article 3(1), Marriage Law of 1974). Relaxation is therefore given for polygyny practice with respect to any husband who desires to marry an additional wife to approach Court permission. The grant of this permission by the Court must ensure active involvement of the first wife (Article 3(2), Marriage Law of 1974). The grant of permission is not procured as a matter of course but on the fulfillment of condition precedents such as the establishment of the inability of the wife to discharge conjugal duties, the establishment of incurable illness being suffered by the wife and establishment of the inability of the wife to bear children (Article 4(2), Marriage Law of 1974). Apart from the fulfillment of the conditions, the law also requires that the husband must satisfy the Court that he shall continue to financially and adequately support the needs of his wife/wives and children and that he shall continue to deal justly and fairly amongst his wives and children. These are to be established before the Court with concrete evidence. And importantly, the first wife must also give permission or consent to the second marriage (Article 5(1), Marriage Law of 1974).

The principles laid down in the Indonesian Marriage Law of 1974 have been guiding the Courts in their dispensation of justice in polygyny-related cases and to a certain extent, it has been effectively enforced (Abdullah \& Khairuddin, 2009). However, a critical evaluation of the law reveals that it absolutely protects the interest of the wives at the expense of the husbands. Under Sharia, polygyny is the natural right of husbands. Wives, by their very nature, detest second marriage by their husbands. Thus, strict adherence to the provisions of the Marriage Law of 1974 has resulted in denial of second marriage in a certain situation (Aisha Abdul Raof vs. Wan Yusuf $7 \mathrm{JH}$ 152 (1990)).

For instance, the husband whose second marriage was declined by the wife and the Court can resort to Zina as evident in Aisah Abdul Raof's case where the husband pleaded with the Court that he felt the apprehension of committing Zina with a proposed second wife should the withhold permission to marry her (Abdullah \& Khairuddin, 2009). Therefore, holding tenaciously to the provisions of the law to refuse to grant permission to a deserving husband constitutes a potential challenge that ought to be revisited. 


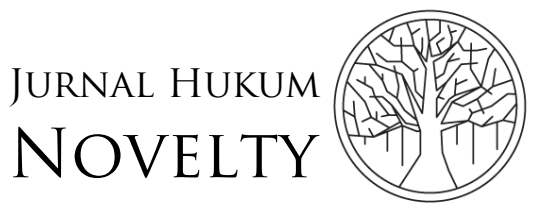

Volume 12, Issue 02, 2021, pp. 204-224

P-ISSN: 1412-6834

E-ISSN: 2550-0090

Little wonder, some men have resorted to secret second marriages without the knowledge of the first wife and his relatives for fear of objection. Although this is a criminal act in Indonesia, but most wives prefer to opt for divorce rather than pressing criminal charges against their husbands (Mudzhar, 2018). Thus, it could be inferred from the above that Islamic polygyny is Allah's guidance which man cannot reject in a desired or pressing situation. The restricted polygamy is, therefore, a reality in the light of the situation on earth in recent times.

\section{Potential Challenges}

The practice of Islamic polygamy is one of the Islamic practices that has been widely criticized from all quarters, even among the Muslim Ummah. The reason is not farfetched. As explained above, most of the Muslim practices are anathema to Sharia teachings (Albaghli \& Carlucci, 2020). Muslims who engage in polygyny have exhibited unjust behavior towards their wifes contrary to the dictates of Sharia. This has prompted feminist arguments in the Muslim arena, which tends to attack the bad practitioners of Islamic polygyny (Mwambene, 2017). Their contention was geared towards criticizing Muslim men who practice polygyny contrary to the rationale behind the revelation of the Quran Chapter 4 verse 3. They are of the view that the very essence of the legislation in verse is to protect the widows and orphan girls and also to enhance that they are not subjected to unjust dealings, especially in marital affairs (Dierickx et al., 2019). The resultant effect has been a bad impression created of the Sharia concept of polygyny among the populace (Dierickx, 2019). This has constituted a serious challenge to the continuous practice of Islamic polygyny.

Another challenge to polygyny under Sharia is the non-submissiveness of most Muslim women to the injunction contained in the Holy Quran (Quran Chapter 33 verse 36). The situation of Quran Chapter 4 verse 3 with respect to restricted polygyny is not an exception. Most Muslim women detest polygyny and can go to any length to prevent their husbands from taking another wife. They cannot withstand sharing their husband with another woman (Ash-Shaqawy, 2021). They perceive polygyny as a serious threat to the extant union between them and their husband and forget to reason behind the wisdom associated with the revelation of the verse of polygyny which includes even engagement of husbandless women in legal marital union and relationships.

Overcoming the challenges associated with polygyny practice lies in attitudinal change among Muslims generally. The practice of polygyny should be done in such a way that it is parallel to the Maqașidus-Sharia (objectives of Sharia) (Al-Qahtani, 2015). Parts of the main objective of Sharia are the preservations of life and honor. Domestic violence constitutes a threat to the life and honor of wives and children. Thus, husbands should at all times be merciful to their wives and children in their polygyny practice and strive to achieve the objective of Sharia vide their marital relationships. Because the Prophet has instructed that institution of marriage is an act of worship. 
Certain laws put into place with a view to preventing abuse of polygyny practice need to be enforced with caution so as not to open the flood gate for illicit sexual intercourse. There is, therefore, the need to strike a balance between the reason for refusal of permission and the consequence of refusal on the part of the affected persons (i.e., the husband and the second wife to be). Sharia Court's ruling must at all times reflect Maqāsidus-Sharia. It is a trite principle of Islamic jurisprudence that Maqāșidus-Sharia is geared towards seeking the attainment of benefit and prevention of hardship in a given situation (Al-Qahtani, 2015). Much as the law (Indonesian Marriage Law, 1974) seeks to prevent hardship on the wives and children from bad polygyny practices, and the Sharia Court must also not forget the benefit of polygyny practice to the husband and the proposed second wife as the case may be (Hedi et al., 2017; Al-Qahtani, 2015).

Thus, it needs to be stated that though the condition of justice and fairness amongst wives is attached to the permission to practice polygyny in the Holy Quran, once the apprehension injustice is absent, the husband has latitude to marry second, third, or fourth wife (As-Sa'di, 2018). The additional conditions of establishment of the wife's inability to carry on conjugal duties, wife's suffering from an incurable illness, or wife's inability to bear children coupled with mandatory procurement of the wife's permission or consent are outside the purview of the intendment of the Law Giver (As-Sa'di, 2018). If such should be the case, the Law Giver would have made such stipulation because such conditions amount to indirectly forbidden what the Law Giver has permitted.

\section{Conclusion}

The provision of Quran Chapter 4 verse 3 is one of the wonderful provisions in the Holy Quran because it does not only satisfy the quest of men for more wives but also takes care of the interest of women, especially the widows, divorcees, orphan girls, and other categories of women who are ripe for the marital experience. Notwithstanding the innumerable benefits of the verse to both sexes, Muslim Jurists are scared to recommend Islamic polygyny out of the fear of the unjust inclination of man, which is embedded in the bad practices discussed above. It must be noted that the reality is that man cannot run away from polygyny practice in the face of certain circumstances warranting it instead of engaging in Zinā. Most Muslim women find it difficult to share their husbands with other women by way of Islamic polygyny in contravention of the injunction in the Holy Quran and admonition of His Messenger (PBUH).

The original mechanism for upholding justice and ensuring that the husband brings maximum justice to his wives and children in polygyny practice is deeply rooted in the Holy Quran Chapter 4 verse 3. By extension, certain climes such as Malaysia and Indonesia have enacted laws to this effect. These laws are the Islamic Family Law of Malaysia and the Indonesian Marriage Law of 1974. The legal framework primarily seeks to prevent unjust practices such as domestic violence, abandonment of the 
needs of wives and children, etc., in polygamous homes. To this end, polygyny is not automatic but by Court's permission after satisfying the conditions stipulated by law geared towards protecting the interest of the wives. The role of Sharia Courts in this regard cannot be over-emphasized in the sense that they cannot be bypassed by any husband desiring to marry a second wife.

Thus, as laudable as the provisions of the laws (Islamic Family Law of Malaysia and Indonesian Marriage Law of 1974), the conditions stipulated for grant of permission to marry a second wife or additional wife need to be revisited to prevent opening flood gate for illicit sexual intercourse since it is difficult to practice polygyny legally. There is a need for Sharia Court while considering applications for permission to marry an additional wife, to strike a balance between the interest of the first wife and the circumstance of the husband. This could be done by weighing the quantum of hardship likely to be caused to the wife or wives vis-à-vis the peculiar situation of the husband, especially to avoid the temptation of Zinā with the proposed additional wife without defeating the original purpose of Quran Chapter 4 verse 3 and the objective of Sharia which primarily focuses on prevention of hardships and attainment of benefits.

It is therefore recommended that Muslim men should carefully study and be acquainted themselves with the legal implication of Quran Chapter 4 verse 3 so as to be able to practice it as an act of 'Ibadah (worship) rather than a self-satisfying gratification. The reason being that it is a serious act that attracts rewards from Allah (SWT) if properly undertaken, and at the same time attracts serious punishment in the hereafter if mal-practiced. The Prophet has warned that those who engage in the bad practice of polygamy will have half of their body paralyzed on the Day of Judgment as a consequence of their actions.

The woman folk, on the other hand, should rise to the occasion by wholeheartedly welcoming the practice of polygyny by their husbands as a duly permitted act by Allah SWT in order not to run afoul of the warning of the Law Giver in the Holy Quran (Quran Chapter 33 verse 36).

\section{Acknowledgment}

I appreciate and duly my colleague (Aishat Abdul Quadri Zubair (Mrs,)) at the Islamic Law Department of Kwara State University is the person who introduced me to this reputable journal with lots of encouragement. And ultimately, I especially appreciate the various anonymous Reviewers whose comments in the course of this research, no doubt, enriched this paper.

\section{Declarations}

Author contribution : Working on the entire content of the script.

Funding statement : This research is funded under personal research and the authors receive no financial support for the research, authorship, and/or publication of this article. 
Conflict of interest $\quad$ : The authors declare no conflict of interest.

Additional information : No additional information is available for this paper.

\section{References}

Abdullah, A. \& Khairuddin, S. (2009). The Malaysian Sharia Courts: Polygyny, Divorce and the Administration of Justice. Asian Women, 25(1), 21-54.

Ahmad, A.B. et al, (2018). The Morphology Aspect of the Quranic Recitation that influence Islamic Laws in Tafseer Ayat Al-Ahkam by Al-Sabuniy. International Journal of Engineering \& Technology, 7(2.29), 316-320.

Ahmed, L. (2021) Women and Gender in Islam, (New Haven: Yale University Press), p. 41

Albader, F. (2019). Breaking the Perceptions of Islamic Monolithism. University of Miami International and Comparative Law Journal, 26(2), 337-368

Albaghli, B. and Carlucci, L. (2020). The Lin between Muslim Religiosity and Negative Attitude towards the West: An Arab Study. International Journal for the Psychology of Religion, 1-14.

Al-Qahtani, M. A. (2015). Understanding Maqasid al-Sharia: A Contemporary Perspective. International Institute of Islamic Thought, UK and USA, ISBN pbk: 978-1-156564-666-7, 1- 25.

Ambali, M.A. (2014). The Practice of Muslim Family Law, Third Edition, Princeton \& Associates Publishing Co. Ltd, Ikeja, Lagos, 1-427.

Aminu, M.Y. (2015). Illegitimate Child (Walad Al-Zina) and His Position in Islamic Succession. Journal of Humanity and Social Science, 20(12)(II), 25-37

Annie, S. (2016). Infertile Muslim Couples Face Tough Choices, Pressure. ALT Muslimah Children Columns, 1. available at http://www.atlmuslimah.com/2016/08/infitile-muslim-couples-face-toughchpices-pressure/ accessed on 22n March, 2021.

Arabian, A. (2016). The Rights and Duites of Spouses in Viewpoint of Koran and jurisprudence. International Journal of Academic Research in Business and Social Science, 6(1), 196-208.

Arthi, V. and Feske, J. (2018). Polygamy and Child Mortality: Historical and Modern Evidence from Nigeria's Igbo. Review of Economic Household, 16, 97-141.

Ash-Shaqawy, A.A. (2021). Hadith Commentary. http://en.aluka.net/Shariah/0/657/ accessed on 22 ${ }^{\text {nd }}$ March, 2021.

As-Sa'di, A.N. (2018). Tafseer As-Sa'di Juz' 4-6, Volume 2, International Islamic Publishing House, Riyadh, 120-123.

Badawi, J. (2021). Polygamy in Islamic Law. http://www.wakf.comarticle>poligamy $>$ in $>$ islamic $>$ law/pdf accessed on 22nd March, 2021.

Batagarawa, K.T. and Yahaya, A.G. (2018). Counting Blessings with Cautions: Wisdom and Vitality of Polygamy in Islam. IOSR Journal of Humanities and Social Sciences, 23(9), 47-53. 
Behaghel, L. and Lambert, S. (2017). Polygamy and the Intergenerational Transmission of Education in Senegal. Workshop Paper on Dynamics of Inequalities in Developing Countries, held at Paris School of Economics, 1-26.

Bidin, S.N.B.S.B., et al. (2017). The Approach of Interpretation by Hamka in Tafsir AlAzhar Based on Scientific Exegesis. International Journal of Academic Research in Business and Social Science, 7(4), 194-207.

Davary, B. (2016). Women and Quran: A Study in Islamic Hermeneutics. The Edwin Mellen Press, 60-61

Dierickx, S, et al. (2019). Women with Infertility Complying with and Resisting Polygyny: An Explorative Qualitative Study in Urban Gambia. Reproductive Health, 16(103), 1-25

Ferdousi, N. (2019). The Practice of Dower and Dowry in Muslim Marriage in Bangladesh: A Legal Analysis. Jurnal Syariah, 27(3), pp. 547-564.

Fowzul, M.B. \& Haneef, S.S.S. (2020). Women's Advocacy for imposing Stringent Stipulations on Polygamy in Muslim Marriage and Divorce Act of SRI LANKA: A Juristic Analysis. International Journal for Studies on Children, Women, Elderlyand Disabled, 11, 2-9

Grossbard, S. and Vernon. V. (2014). Common Law Marriage and Couple Formation. Discussion Paper, No. 8480, San Diego State University, San Diego, CA, USA.

Gusau, M. (2021). The Bad Consequences and Dangers of Adultery and Fornication in Islam. http://opinion.premiumtimesng.com/2017/07/04/thebad-consequences-and-dangers-of-adultery-and-fornication-in-Islam-bymurtadha-gusau/> accessed on 22nd March, 2021.

Hashemian, M.H. (2020). Why is Polygamy Permissible in Islam? International Conference on Jurisprudence, Law and Religious Research, 1-12.

Hassan-Bello, A. (2019). Sharia in the Nigerian Constitutions: Examining the Constitutional Conferences and the Debates in the Drafts. Al-Ahkam, 29(1), 126.

Hedi, F. (2017). Legal Interfaith Marriage in Indonesia. Hasanuddin Law Review, 3(3), 263-276.

Husain, R.T. et al. (2019). Polygamy in the Perspective of Hadith: Justice and Equality among Wives in a Polygamy Practice. Madania, 23(1), 93-104.

Ibn Kathir. (2021). Tafsir: An-Nisa. http://www.recitequran.com/tafsir/en.ibn/kathir/4:3 accessed on 22 nd March, 2021.

Ishola, A.S. and Abdulrahman, M.M. (2018). Journal of Islamic Law Review, 14(2), 285313.

Ismail, W.N.H.W. et al. (2020). Hudud: The Right of Allah SWT in Perspective of Punishment for Adultery. Journal of Critical Review, 8(8), 789-810.

Krieger, T. \& Renner, L. (2020). Polygyny, Inequality, and Social Unrest. The Economist, 1-57.

Krieger, T. and Renner, L. (2018). A Cautionary Tale on Polygyny, Conflict and Gender Inequality. Discussion Paper Series, 2, 1-28. 
Lawson, D.W. and Gibson, M.A. (2018). Polygamous Marriage and Child Health in SubSaharan Africa: What is the Evidence for Harm?. Demographic Research, 39, 177-208.

Mudzahr, M.A. (2018). The Use and Misuse of Maslaha by the Court in Granting Polygyny Permissions. Proceedings of the First International Conference on Recent Innovations (ICRI), 1038-1044.

Muhammed-Mikaaeel, A.A. (2020). Emergence of Usulul Fiqh under Sharia: From Developmental to Standardization Stage. Maiduguri Law Journal (MLJ), 18, 404-408.

Muhammed-Mikaaeel, A.A. (2020a). Capital Punishment in Nigerian Courts: The Position of Abolitionists vis-à-vis Islamic Jurisprudence. Prof. E.T. Yebisi, et al, (eds.) Law, Policy and Development Review, EKSU Printing Press, Ado-Ekiti, 205-223.

Mwambene, L. (2017). What is the Future of Polygyny (Polygamy) in Africa?. PER/PELJ, 20, 1-33.

Naseem. H. (2019). Best among you is best to his Wife. Faith Matters, November, 30, 2019

Nisa, E. (2016). Marriage Practices: Indonesia. In Joseph, S. (Ed.), Encyclopedia of Women \& Islamic Culture online Brill, available at https://doi.org/10.1163/1872-5309 ewic COM 002088 accessed on 3rd June, 2021.

Nuhu, A.L. (2018). Islamic Law of Inheritance: a Comparative Perspective, Malthouse Press Limited, Lagos, 1-182

Olasore, R.E. (2016). The Extent of Polygamy in Africa, Any Role for the Information Professionals in Curbing Further Spread?. Information and Knowledge Management, 6(6), 7-14.

Ozyigit, M.K. (2017). The Meaning of Marriage According to Students: A Phenomenological Study. Educational Science: Theory and Practice, 17(2), 679-711.

Rahman, Z.A. (2018). Internal Factors that Lead to Crime Rape According to Islamic School in Malaysia. International Journal of Business and Social Science, 9(2), 204-209.

Rogozen, S. (2017). Prioritizing Diversity and Autonomy in the polygamy Legalization Debate. UCLA Women's Law Journal, 24(107), 107-149.

Ross, C.T. et al, (2018). Greater Wealth Inequality, Less Polygyny; Rethinking the polygyny Threshold Model, Journal of Royal Society, 15, 1-15.

Salman, K.O. (2019). An Analysis of the Primary Sources of Sharia. Maiduguri Law Journal (MLJ), 17, 341-347.

Sharmin, S.S. and Azad, M.M. (2018). Laws of Muslim Marriage from the Concept of the Holly Quran. International Journal of Engineering and Applied Sciences, 5(7), 29-32. 
Shih, P. et al. (2017). Good Culture, Bad Culture: Polygyny, Cultural Change and Structural Drivers of HIV in Paupa New Guinea. Culture, Health and Sexuality, 19(9), 1024-1037. 